\title{
Prevention and repression : food supply and public order in early modern Madrid
}

\author{
Angel Alloza Aparecio, José Miguel López García, José Luis de Pablo Gafas
}

\begin{abstract}
In early modern Madrid, food supply and public order inevitably became a matter involving the state. The Spanish Crown responded to these challenges by mobilizing two institutions : the Council of Castile and the Chamber of Magistrates of the Royal Household and Court. Officers of both institutions tried to prevent social disorders and food riots through an interventionist and centralised model of provisioning. However, social and financial costs of this system soon proved excessive : on the one hand, the cheap bread of Madrid was paid for by rural producers and urban consumers, while on the other, the need for public subsidies worsened the financial difficulties of the royal and municipal Exchequers. After the failure of this traditional system, and rising levels of crime and poverty registered in Madrid, the absolutist state ended up with only means of preventing and repressing public disorders : the increase of police control over the city, by endowing the Chamber of Magistrates and the Royal Army with more coercive powers.
\end{abstract}

\section{Citer ce document / Cite this document :}

Alloza Aparecio Angel, López García José Miguel, Pablo Gafas José Luis de. Prevention and repression : food supply and public order in early modern Madrid. In: Mélanges de l'Ecole française de Rome. Italie et Méditerranée, tome 112, n². 2000. Les images de la Grande Guerre en France, Allemagne et Italie. Actes de la table ronde organisée par l'École française de Rome en collaboration avec l'Università di Roma «La Sapienza» et le Deutsches historisches Institut in Rom, 6 et 7 novembre 1998. pp. 615-644;

http://www.persee.fr/doc/mefr_1123-9891_2000_num_112_2_10883 


\title{
PREVENTION AND REPRESSION : FOOD SUPPLY AND PUBLIC ORDER IN EARLY MODERN MADRID
}

\begin{abstract}
Magistrates should be most concerned about and take measures regarding bread shortages. These are frequent in the winter periods of rain and snow, and especially pronounced in the months of April, May and June during years of poor harvests. To remedy this magistrates and constables are assigned to the entire area of Madrid... ${ }^{1}$.
\end{abstract}

The demographical expansion which affected early modern European capital cities became a permanent source of worry for their authorities. Thanks to this constant population growth, interrupted only in a few cases during the seventeenth century crisis, capital cities were transformed into the principal markets of Western Europe at the end of the Ancien Régime ${ }^{2}$. The origin of the expansion of these cities was linked to the presence of the central apparatus of absolutist states; the engine of growth itself was based upon the migration of huge numbers of starving peasants from the countryside ${ }^{3}$.

Until the early decades of the eighteenth century, the existing supply of manpower in these cities could absorb a large part of the newcomers.

* Equipo Madrid de estudios históricos. Universidad autónoma de Madrid.

${ }^{1}$ Advertencias para el exercicio de la plaza de alcalde de casa y corte, según están en un libro antiguo de la Sala, que es el que cita el señor Matheu, por anotaciones del señor Elezárraga, con las notas marginales con que se halla hasta el presente año de 1745. Capítulo 35. Archivo histórico nacional (hereafter A.H.N.), Consejos, libro 1.420 .

${ }^{2}$ For their evolution, see P. Clark y B. Lepetit (ed.), Capital cities and their Hinterlands in early modern Europe, Aldershot, 1996.

${ }^{3}$ See W. Kula, Recherches comparatives sur la formation de la classe ouvrière, in Second ICEM, Paris-The Hague, 1960, p. 510-523. For the crucial role of migration in the growth of preindustrial cities, see J. De Vries, La urbanización europea, 15001800, Barcelona, 1987, p. 258-322 and J. M. López García, Las ciudades europeas en la transición al capitalismo : ¿urbanización o urbanizaciones?, in Historia urbana, 2, 1993 , p. $71-83$, p. 72 . 
Then, with the exception of the big maritime metropolis, the demand for jobs in important sectors such as domestic service, construction, manufactures, and commerce tended to stagnate. This tendency led to a perceptible decline of wages, the main source of income of the menu peuple, whose family units represented more than a half of the population of most capital cities ${ }^{4}$.

While expectations of finding jobs decreased, migration from rural to urban centres intensified. In these circumstances, by the end of the Old Regime the disinherited represented more than a sixth of the population of Paris and London. In the streets the newcomers mixed with the existing metropolitan poor. Indeed, some 50 per cent of the urban population lived near or below the limits of subsistence. For these people, the principal aim of everyday life was to obtain an abundant portion of bread ${ }^{5}$.

Some of the people living in such straitened economic conditions felt fully justified in abandoning legality and joining the criminal underworld, thus challenging the public order and its authorities. The response to the trend toward increasing criminal behaviour was identical in most of the big cities : hard punishment for serious offenders, the criminalization of poverty, and confinement of the poor into Hôpitaux généraux, hospicios, and workhouses, where they were to be re-educated in the culture of work, through service in these urban institutions, or sentencing to hard labour or service in the Royal Army ${ }^{6}$.

If others did not go that far, this was because they could relieve their penury somewhat through charity, thanks to a poor relief system sponsored by municipal governments, the Crown, and the Church. Another

${ }^{4}$ For the expansion of employment in London, see L. D. Schwarz, London in age of industrialization : labour force and living conditions, Cambridge, 1992. For the living conditions and impoverishement of a large part of the population of other cities, see G. Rudé, Europa en el siglo XVIII. La aristocracia y el desafío burgués, Madrid, 1978, p. 89-90; C. Lis y H. Soly, Pobreza y capitalismo en la Europa preindustrial (1350-1850), Madrid, 1985, p. 191-207; and M. Montanari, El hambre y la abundancia. Historia y cultura de la alimentación en Europa, Barcelona, 1993, p. 128-149.

${ }^{5}$ For the size and characteristics of the European population living below the limits of subsistance, see G. Rudé, Europa, p. 90-91; O. Hufton, The poor in eighteenth-century France, 1750-1789, Oxford, 1974, and S. Woolf, La pobreza en el Europa Moderna, Barcelona, 1989.

${ }^{6}$ This process was defined by Michael Foucault as «the great confinement». See his study, Folie et déraison. Histoire de la folie à l'âge classique. Paris, 1961. For the repressive policies converging in early modern European states, see C. Lis y H. Soly, Policing the early modern proletariat, 1450-1850, in D. Levine (ed.), Proletarization and Family History, New York, 1984, p. 163-228. 
important cause was that capital cities were very well supplied with bread and other basic food-stuffs. Under these circumstances, the problems originated by the expansion of the ranks of the poor, and the challenges posed by the prevention and repression of criminality and in particular the efficient provisioning of these centres, traditionally confided to the urban police, soon became a source of major conflicts. Thus, from the 16th to the 18th centuries, these tasks were by and large assumed by institutions linked to the central apparatus of the absolutist states. In Paris, Naples, Rome, and Madrid, food supply and public order became a matter involving the state ${ }^{7}$.

The tendency towards intervention by absolutist states in the government of their capitals intensified during the Iron Century. The consolidation of the continental Courts developed in tandem with a growing exaltation of the king's image, whose power not only was proclaimed as legitimated by divine origin, but also by his model behaviour in the administration of justice, the maintenance of the peace, and the extension of poor relief. In fact, one of the most relevant elements of this propagandistic display was the exercise of the social patronage of the monarchy within the city in which its court was established ${ }^{8}$.

Although the exercise of royal patronage in capital cities led to high

${ }^{7}$ In Early Modern Europe the words Polizei, police, or policía continued to be linked to their original Greek meaning, reference to a series of responsibilities related to the good government of the city. Among them stand out those devoted to the prevention and correction of disorder, of a hygienic, urbanistic, or criminal nature; or in relation to the provisioning of the city's markets and the prevention of food riots. In the capital cities, these matters were supervised by royal or central institutions, superposed upon the municipal councils. For more on these questions, see C. Tilly, Food supply and public order in modern Europe, in C. Tilly (ed.), The formation of national states in western Europe, Princeton, 1975, p. 380-455, especially p. 440-43; and F.-L. Knemeyer, Polizei, in Economy and Society, 9, 1980, p. 172-196. Examples of the juxtaposition of institutions can be found in J. Jacquart, Paris : First Metropolis of the early modern period, in P. Clark y B. Lepetit (ed.), Capital, p. 105118, especially p. 115, and B. Marin, Naples : capital of the Enlightenment, ibidem, p. 143-167, especially p. 145, 157; and Á. Alloza Aparicio, La economía criminal de los desheredados. Estudio comparativo de Londres, Madrid, París y Amsterdam en el siglo XVIII y comienzos del XIX, in Revista internacional de sociología, 23, 1999, p. 173-205.

${ }^{8}$ The theoretical foundations of royal power are studied in J. A. Maravall, $L a$ cultura del Barroco, 2a ed. Madrid, 1983; P. Fernández Albaladejo, Fragmentos de Monarquía, Madrid, 1992, p. 63-105; and P. Burke, La fabricación de Luis XIV, Madrid, 1995, p. 12-21. For the consolidation of absolutist states and their royal courts in the sixteenth century, see P. Anderson, Lineages of the absolutist state, London, 1974 and J. Miller (ed.), Absolutism in seventeenth-century Europe, Hampshire-London, 1990. 
expenses for Royal Exchequer, its functioning was essential to prevent food riots. The proliferation of this type of conflict in early modern European cities was a manifestation of a determined defense of what E. P. Thompson has called the "moral economy of the crowd». Fear of these revolts increased visibly in the second half of the eighteenth century. As the authorities correctly perceived, the danger of these tumults lay not so much in the damages they caused nor their threat to the credibility of the absolutist state. The real peril was the possibility of an agreement between the masses and certain élites to undertake to change the state, or to remove the leading officers of the royal government ${ }^{9}$.

With the aim of preventing disorder, a number of treatises on urban police and government of the court were published in Naples, Madrid and Paris in the course of seventeenth and eighteenth centuries, all of them devoted to the control of urban space and to the correct provisioning of markets in the capital cities ${ }^{10}$.

Case studies of bread supply in early modern capital cities provide a good example of the nature of all the measures mentioned thus far. They clearly show that royal authorities implemented mechanisms of intervention which had already been used in urban centres since the late Middle Ages. From a spatial point of view, early modern authorities tended to extend the hinterland under municipal jurisdiction inherited from

${ }^{9}$ For an analysis of eighteenth-century rebellions, see G. Rudé, La multitud en la historia. Los disturbios populares en Francia e Inglaterra, 1730-1848, Buenos Aires, 1971. The political culture of popular classes and its demostration in the market is studied in E. P. Thompsom, La economía 'moral' de la multitud en la Inglaterra del siglo XVIII and La economía moral revisada, in Costumbres en Común, Barcelona, 1995, p. 213-398. For the connection between royal legitimacy and "fair government» (gobierno justo), see B. Moore, Jr., Injustice. The social bases of obedience and revolt, New York, 1978. For the fear of governments of the participation of the popular classes in an attempt to change the state, see R. Villari, Revueltas y consciencia revolucionaria en el siglo XVII, in Rebeldes y reformadores del siglo XVI al XVIII, Barcelona, 1981, p. 13-41.

${ }^{10}$ Such is the content of the books by F. Freza (1623), J. de Elezárraga (ca. 1650) y N. Delamare (1705). For an analysis of their contents, see G. Sabatini, Il pane di cerbero. Aspetti di politica annonaria e demografica a Napoli nell'età di Filippo II, in J. Martínez Millán (dir.), Felipe II (1527-1598). Europa y la Monarquía Católica, Madrid, 1998, vol. 1.2, p. 767-776; A. Domínguez Ortiz, Aspectos del vivir madrileño durante el reinado de Carlos II, in Anales del Instituto de estudios madrileños, VII, 1971, p. 229-252; J. L. de Pablo Gafas, Justicia, gobierno y policía en la corte de Madrid: la Sala de Alcaldes de Casa y Corte (1583-1834), Ph.D. diss., Universidad autónoma de Madrid, 2000, p. 279-500; C. Tilly, Food supply cit., p. 441; P. Fraile, Putting order into the cities : the evolution of 'policy science' in eighteenth-century Spain, in Urban history, 25.1, 1998, p. 22-35. 
medieval times. Once the new districts were consolidated, peasants within this area were obliged to sell wheat and bread in the urban market, or to sell it directly to the municipal authorities at a fixed price ${ }^{11}$. In years of poor harvests, political intervention intensified, and the municipal authorities exercised their power by making purveyances of bread and above all by establishing ceiling prices of wheat in the market. This obliged peasants to sell a quota of their produce at much lower prices than they could obtain in the free market to the royal officers or merchants charged with supplying the capital city. The iron control over the bread supply extended into the own urban markets, where municipal and royal officers supervised daily the bread's weight and quality, and stipulated its maximum prices ${ }^{12}$.

In Portuguese, Italian, and Castilian cities, and also in certain French urban centres, the supply of wheat was assured through the construction of public granaries where supplies acquired by merchants were stored. These cereals were subsequently sold by the granary officials at politically determined prices during periodic subsistence crises, in order to guarantee this essential product to the population. Otherwise the lack of bread could culminate in riots, a constant and serious threat to this precarious social order $^{13}$.

Within the capitals, the maintenance of public order was also pursued through the expansion of the size and tasks of judicial and police institutions. This process culminated in the participation of soldiers of the regular army in the maintenance of the peace. This phenomenon was also accompanied by a hardening of the criminal law, especially against those

${ }^{11}$ That was the case of early modern Paris, whose court district comprised some $31,400 \mathrm{~km}^{2}$, an area much larger than the original hinterland of the medieval town which still existed in 18th century. See J. Jacquart, Paris, p. 118-110, and Y.-N. Genty, Le domaine de la Ville de Paris au XVIII siècle, Paris, 1986.

${ }^{12}$ The case of Paris is studied in S. L. Kaplan, Les ventres de Paris, Paris, 1988; the case of Rome, in V. Reinhardt, Annone and bread supply in Rome, in P. van Kessel and E. Schulte (ed.), Rome-Amsterdam : two growing cities in seventeenthcentury Europe, Amsterdam, 1997, p. 209-220; for Naples, see P. Macry, Mercato e società nell Regno di Napoli. Commercio del grano e politica economica del '700, Naples, 1974. During the early modern period, the ceiling price of bread was maintained in Southern capital cities. But even in a very liberalized market such as London, the bread's weight, quality, and price was also supervised until 1805 by the Assize of Bread, lead and managed by Justices of the Peace. See C. de Castro, El pan de Madrid. El abasto de las ciudades españolas del Antiguo Régimen, Madrid, 1987, p. 22-24, and E. P. Thompson, La economía moral revisada, p. 328.

${ }^{13} \mathrm{~F}$. Braudel, La Méditerranée et le monde méditerranéen à l'époque de Philippe II, Paris, 1966, vol. I, p. 300-334, y C. de Castro, El pan, p. 95-96. 
who committed property offences, or who were simply charged with the crime of vagrancy ${ }^{14}$.

\section{Bread and justice}

In the Spanish capital, the population multiplied by 6.5 from 1561 to 1630, when it peaked at around 130,000 inhabitants. By this point, Madrid had become one of the ten largest cities in Europe ${ }^{15}$. This singular expansion took place in the midst of a general crisis in which Castile lost 25 per cent of its inhabitants, its agrarian production suffered a considerable decline, and the entire kingdom experienced a process of deurbanization. Simultaneously, agrarian surpluses tended to concentrate in the hands of the nobility, religious institutions and Royal Exchequer. In these circumstances it is not difficult to understand why the demographic growth of Madrid caused by massive immigration from all of Castile was a serious source of worry for municipal authorities, those obliged in the first instance to assure food for everyone ${ }^{16}$.

From the beginning the Spanish Crown responded to this challenge by means of a specific institution of medieval origin : the Sala de Alcaldes de Casa y Corte (literally, the Chamber of Magistrates of the Royal Household and Court), which had acquired definitive shape in 1583. This royal institution overlapped with the municipal council, whose president - the Corregidor - was also designated by the Council of Castile, and who assumed all tasks in relation to government, justice and the policing of Madrid. To carry out all these functions, the magistrates divided Madrid into different districts (cuarteles), whose number grew from 4 in 1583 to 10 in 1678. They also established a system of control based on night patrols,

${ }^{14}$ The increase in harsh punishments and social control, and the improvement of police in Paris and London, in A. Williams, The police of Paris, 1718-1789, Baton Rouge-London, 1979; D. Hay and F. Snyder, Using the criminal law, 1750-1850. Policing, private prosecution, and the state, in Policing and prosecution in Britain, 1750-1850, Oxford, 1989, p. 3-52; and R. Paley, An imperfect, inadequate and 'wretched system'? Policing London before Peel, in Criminal justice history, X, 1989, p. 95-130. About the extension of the English «bloody code», see D. Hay, Property, authority and the criminal law, in Albion's fatal tree : crime and society in eighteenth century England, Bristol, 1975, p. 17-63.

${ }^{15}$ For demographic evolution of Madrid from 1561 to 1630 , see M.F. Carbajo Isla, La población de la Villa de Madrid desde finales del siglo XVI hasta mediados del siglo XIX, Madrid, 1987, p. 224-227.

${ }^{16}$ For social changes, the transformation of urban space, and policing in seventeenth-century Madrid, see J. M. López García (dir.), El impacto de la Corte en Castilla. Madrid y su territorio en la época moderna, Madrid, 1998, p. 151-266. 
and the inspection of markets, public storehouses, fairs, and theatres by constables (alguaciles) under their supervision. Outside the city, the Chamber also created a jurisdictional district that included villages situated within a 30 kilometre radius, the so-called Rastro de la Corte ${ }^{17}$.

In order to assure the city's bread supply, the Sala used a system which they named the Pan de Registro. This involved a compulsory mechanism similar to the one employed by urban seigneuries beginning in the Middle Ages, and now extended to a much larger area of supply. Villages and hamlets within it were obliged to divert weekly shares of bread and wheat to the public granary, the Casa de la panadería, where the shares were registered and assigned a fixed sale price. To make sure that the villages under obligation were able to keep up with the capital city's demand, they were also obliged to store part of their surplus in local mini-depots called positillos de Corte. Between 1580 and 1664, the area covered by the Pan de Registro extended, in accordance with fluctuations in grain output, to a radius of $55 \mathrm{Km}$, and in periods of especially acute shortages to up to 110 $\mathrm{Km}$. The overall amount of bread sequestered also fluctuated in accordance with the needs of Madrid. In 1584 the bread acquired under this system accounted for some 40 per cent of the bread consumed in Madrid. In 1664 it reached 66 per cent, thus converting the Pan de Registro into the single largest source of supply for the court. By the 1630's the Pan de registro area included some 500 villages and towns situated in the present-day provinces of Madrid, Toledo, Guadalajara, Ávila, and Segovia, and covered an area of $34,854 \mathrm{Km}^{218}$.

At the same time, in order to prevent food riots caused by grain shortages the Pan de Registro system developed a complementary strategy of storing reserves of wheat in the Pósito, which provided bakers with grain

${ }^{17}$ The origins and definitive consolidation of the Sala de Alcaldes is studied in J. L. de Pablo Gafas, La invención de la Corte : la creación de la Sala de Alcaldes y el proceso de modernización institucional en el reinado de Felipe II (1561-1598), in J. Martínez Millán (dir.), Felipe II, vol. 1.2, p. 579-594. A more detailed analysis of its functions by the same author is found in Justicia, gobierno, p. 279-379. For the distribution of urban space in cuarteles and the Rastro de la Corte, see Id., Las circunscripciones civiles en la Edad moderna, siglos XVI-XIX, in V. Pinto Crespo and S. Madrazo Madrazo (ed.), Madrid, Atlas histórico de la Ciudad. Siglos IX-XIX, Barcelona, 1995, p. 126-131, and plan n. 121.

${ }^{18}$ For the evolution of this peculiar system of bread supply, see J. U. Bernardos Sanz, No sólo de pan. Ganadería, abastecimiento y consumo de carne en Madrid (1450-1808), Ph.D. diss., Universidad autónoma de Madrid, 1997, p. 71-78 and 305322. 
during subsistence crises. Until 1590 the grain storehouse acquired its reserves through a contract system involving specially designated merchants. These contracts specified the areas from which wheat was to be bought - they deliberately excluded that of the Pan de Registro - and fixed the dates for the delivery of the produce, along with the middlemen's profits. From 1590 on, some changes took place in the oversight of this arrangement. These ended up in the creation in 1630 of the Junta del Pósito, a royal committee made up of the president and four members of the Council of Castile, a magistrate of the Chamber, the Corregidor, and two aldermen. The costs of administration of the new institution created to deal with the grain supply led to an enormous debt, which had to be assumed by the Municipal Council and eventually by the Royal Exchequer. The debt originated above all in the Junta's practice of selling grain to bakers at prices lower than the purchase price in order to avoid food riots.

In order to defray the debt of the Pósito and the interest rates of the loans floating it, the royal authorities levied new indirect taxes on consumer goods (sisas). Thus, in the end, the members of the popular classes wound up paying a full price and more for the cheap bread they consumed. Both urban bakers and rural producers were obliged to buy and sell grains from and to the Pósito at higher prices, in order to ensure the stocks of the Madrid's municipal granary ${ }^{19}$.

Such obligations produced tensions in the rural economy. Rural communities showed in a number of occasions their discontent with the price ceilings imposed by the royal authorities, especially when during production crises peasants were forced to sell to the public granary in Madrid more than 10 per cent of their output at much lower prices than those prevailing in the free market. However, in good harvest years, peasants had to acquire wheat from the public granary at higher prices than in the market. This situation clearly prejudiced peasant communities around Madrid ${ }^{20}$.

Under these circumstances, the evolution of Castilian society during the seventeenth century crisis led to changes in the compulsory system of supply. A combination of subsistence crises, greater specialization in rural production in wine, barley, and other foodstuffs, exemptions purchased by about 20 localities in order to avoid the Pan de Registro, and peasant resistance against such pressures, drove the authorities to increase the compulsory area of bread supply. At the same time the system proved to be

${ }^{19}$ See J. M. López García (dir.), El impacto cit., p. 335-344.

${ }^{20}$ Different reports on prices and obligations can be found in Archivo de Villa de Madrid (hereafter A.V.M.), Secretaría, 2-96-1. 
increasingly vulnerable. As a result, in 1699 the villages subject to the Pan de Registro owed 90.67 per cent of the shares of bread they were obliged to contribute, while the officers of the Sala de Alcaldes helplessly looked on as the local mini-depots - positillos de Corte - decayed through lack of use ${ }^{21}$.

Within the city, the situation became even more difficult. Twenty thousand impoverished migrants reached Madrid in 1699, fleeing from the hunger that extended throughout Castile. Their needs clearly exceeded the capacity of the existing institutions of charity, as well as the means traditionally employed by the Sala de Alcaldes to keep the peace and the public order. In that particular year the market price of bread doubled, while real salaries declined and unemployment levels reached new heights. Apart from that, a general feeling of frustration pervaded the populace, convinced as it was that authorities and rentiers had hoarded grain in order to speculate with it. All this led to the large food riot in the spring of 1699 known as Motin de Oropesa, in which a crowd made up of bricklayers, artisans of all types, labourers, and the poor surrounded the Palace of the king's favourite Oropesa. At the same time another group entered the Royal Palace and demanded the dismissal of both Oropesa and the Corregidor, along with a reduction in bread prices and the rise of the official maximums for grain prices. Finally the populace called for the pardon of the rioters. All these petitions were accepted by the dying king Carlos II, who at the same time apologised for his passivity in the face of the extreme conditions suffered by the poor. This fact somehow legitimized the actions of the revolt ${ }^{22}$.

The aristocratic supporters of the Bourbon candidate to the kingdom of Spain saw that things could not continue to go on this way. It was necessary to reform the whole institutional structure of the capital city, and to introduce improvements in its system of supply in order to avoid similar food riots and other public disorders in the future.

\section{Urban expansion and institutional reforms}

From 1740 onward Europe experienced a new phase of economic expansion which continued until the end of the eighteenth century. In Castile, the recovery that began during the reign of Carlos II was fuelled by impressive demographical growth, in which the population increased by

${ }^{21}$ A.H.N., Consejos, Leg. 51.440. Exp. 2; and C. de Castro, El pan, p. 193-205.

${ }_{22}$ The number of people arriving in Madrid in 1699, in Biblioteca Nacional (hereafter B.N.), Manuscritos, 12.964-10. For a more detailed analysis of the Motin de Oropesa, see J. M. López García (dir.), El impacto cit., p. 477-479. 
23.6 per cent from 1749 to 1797 , and reached the earlier peak level of 1590 . However, this growth was based upon extensive agrarian production, which led to declining agricultural productivity and a rapid rise in food prices. This was one of the elements which further intensified the process of social polarization. Indeed, large-scale rentiers benefited from the increase in prices and the liberalization of the commerce in grains undertaken by enlightened government. At the same time, small and medium peasants suffered progressive impoverishment, aggravated by the increase in subsistence crises in the second half of the eighteenth century ${ }^{23}$.

In consequence, property and wealth within the villages in the hinterland of Madrid tended to concentrate in the hands of a few. By 1760 a group of 36 absentee landowners, including the Royal Household, the Municipal Council, 14 members of the nobility, and 7 religious communities, owned 32.27 per cent of the old alfoz (hinterland). On the other side, the 67 per cent of villagers and rural labourers did not own any property. Thus the main part of agrarian surplus produced in peasant holdings was transferred to persons not involved in the productive process. In fact, this group of absentee landlords absorbed 40 per cent of the surpluses from small farms through land rent, while clergy took 25.84 per cent of this surplus through tithes, jurisdictional lords almost another 10 per cent, and the Royal Exchequer some 14.56 per cent. For a peasant economy, any setback - such as the loss of a crop or of a member of the family - could mean getting into debt, and thus losing the tiny amount of one's inheritance. The end result was enlistment in the army of poor migrants ${ }^{24}$.

The intensification of migration to Madrid underlay the demographic expansion of the city. The eighteenth century began with a new crisis

${ }^{23}$ The increase in the number of baptisms in the Crown of Castile is reported in D.-S. Reher, Auge y declive del mundo urbano de la Corona de Castilla durante la Edad moderna. Aspectos de un reajuste de largo alcance, in L. A. Ribot García and L. de Rosa, Ciudad y mundo urbano en la época moderna, Madrid, 1997, p. 45-72, figure 2. For the characteristics and contradictions of this new phase of growth, see G. Anes Álvarez, Las crisis agrarias en la España moderna, Madrid, 1970, p. 209-226; Á. García Sanz, El interior peninsular en el siglo XVIII : un crecimiento moderado y tradicional, in R. Fernández (ed.), España en el siglo XVIII. Homenaje a Pierre Vilar, Barcelona, 1985, p. 630-680; and A. Marcos Martín, España en los siglos XVI, XVII y XVIII. Economía y sociedad, Barcelona, 2000, p. 552-629.

${ }^{24}$ The concentration of rural property and the characteristics of the distribution of agrarian surplus in the hinterland of Madrid is studied in J. M. López García (dir.), El impacto cit., p. 250-266, and 277-322. 
caused by the War of Spanish Succession (1701-1714) and a major subsistence crisis in Castile in 1709, which left Madrid with 109,000 inhabitants. By the 1740's the city had regained the level of population registered during the seventeenth century, 130,000 inhabitants. The population continued to grow, reaching 190,000 by the end of the century ${ }^{25}$.

The demographical structure reveals some interesting aspects of the society of the capital. During the biggest part of the 18th century the population of Madrid was characterized by a high proportion of adults, between 15 and 50 years of age (more than the 60 per cent of the whole population). Young people only constituted 25 per cent. Moreover, the lack of young people was caused by a high percentage of males with respect to females (more than the fifty per cent of the total). Thus migration definitely reinforced the general trend of growth of the urban population ${ }^{26}$.

Madrid was attractive to migrants because it was the most important city of Spain. During the eighteenth century the capital housed some 2 per cent of the population of Castile, while its political role favoured the concentration within its walls of 17 per cent of the wealth of the whole kingdom. Of the 432 million reales that flowed into Madrid in 1753, 187 accrued to the Royal Exchequer. More than a hundred belonged to different lords and members of the court nobility, and 29 to the clergy. This enormous sum of money was distributed very unequally: the Royal Household, aristocracy, clergy and bureaucrats obtained 80 per cent of it. Labourers, artisans, shopkeepers, and servants retained only the remaining 20 per cent. This situation not only transformed Madrid into a city of services, whose level of consumption exceeded its level of production, but also determined the nature of the capital's demand ${ }^{27}$.

At the summit of Madrid's society stood a selected group of members of the ruling class. This group included the Monarchy and its 6,000 civil servants-officers of the Royal Household, state bureaucrats and ambassadors; 200 aristocrats; 3,000 members of the lower nobility; and a hundred ecclesiastical institutions with about 4,600 members during the period under consideration, with obvious differences among them, apart

${ }^{25}$ M.F. Carbajo Isla, La Población, p. 49-51, p. 227-230.

${ }^{26} \mathrm{~J}$. Soubeyroux, Pauperismo y relaciones sociales en el Madrid del siglo XVIII (1), in Estudios de historia social, 12-13, 1980, p. 7-227, p. 18-27; and M. F. Carbajo Isla, La población, p. 120.

${ }^{27}$ See D. R. Ringrose, Madrid and the Spanish Economy, 1560-1850, BerkeleyLos Angeles, 1983, p. 66-81; and J. M. López García (dir.), El impacto cit., p. 267-268. 
from the general hegemony of regular clergy. Below this group was situated another segment of the population which included merchants nearly 600, of whom some 300 belonged to the Five Major Guilds (Cinco Gremios Mayores) - and about 1,500 persons from the middle classes: lawyers, physicians, professors, and other liberal professionals, whose annual income fluctuated between 5,000 and 15,000 reales ${ }^{28}$.

Below an annual income level of 5,000 reales lived the remaining 80 per cent of Madrid's population. Briefly put, the occupational structure of the period featured activities such as domestic service, which accounted for 20 per cent of the working population of Madrid; construction, which employed about 11,000 people; and around 100 manufacturing trades, including 11,000 persons (above all tailors and shoemakers) along with several thousand others working in food processing and petty commerce. There followed a huge group of unskilled workers, including women and children, who lived in permanently precarious conditions. From 1750 onwards the supply of jobs fell sharply, which meant thus economic hardship for a large part of the working population. Unemployment and migration came hand in hand during the second half of the eighteenth century, when at least 50 per cent of Madrid's population did not pay direct taxes, and lived near or beneath the poverty line ${ }^{29}$.

The precarious situation of the popular classes worsened in the second half of the eighteenth century. During that period, the population grew by 27 per cent, an increase much larger than that registered in the number of available jobs. This led to a rise in unemployment, together with a progressive deterioration of the purchasing power of the working population. Thus, for example, the real wages of bricklayers and other workers in the construction sector dropped dramatically - by half - from 1796 to 1800 . At the same time, the supply of houses also decreased, and housing became an authentic nightmare : the 97 per cent of the urban population rented its lodgings. Around 300 families possessed 69 per cent of the built-up area, along with 48.72 per cent of the city's real estate. Housing rents doubled, and reached 30 per cent of the purchasing power of a typical couple comprising a bricklayer and a domestic servant, genuine representatives of the larger productive sectors. Finally, the fiscal pressure exercized by municipal and royal tax collectors persisted at maximum

${ }^{28}$ See J. Espinosa et al., Consolidación y límites de la ciudad en el siglo XVIII, in Madrid, Atlas, p. 194-209, and J. U. Bernardos Sanz, No sólo de pan, p. 557-559.

${ }^{29}$ For an analysis of the social structure of early modern Madrid, see J. M. López García (dir.), El impacto cit., p. 377-408, and 435-446. 
levels, especially through indirect taxes upon consumer goods, which absorbed 30 per cent of a modest family's annual income ${ }^{30}$.

The growing polarization of society determined Madrid's market structure. Thanks to it, a large part of the population could afford only a few products, while a small minority had greater possibilities of diversifying its demand. The value of food-stuffs and goods imported into the city in 1789 can be calculated as follows : subsistence goods such as wheat, wine, meat, fish, barley, oil, and charcoal represented 40.1 per cent of the total. Other food-stuffs such as sugar, chocolate, and fruits made up 16.2 per cent; manufactured goods took up 37.2 per cent; and diverse raw materials and semi-elaborated goods, the remaining 6.4 per cent ${ }^{31}$.

Within the group of essential products, wheat played a major role. It represented the bulk of trade goods entering the capital, summing up 33,654 tons a year. In terms of weight, wheat imported to Madrid equated the weight of meat, fish, oil, legumes and fruits taken together. Because of its significance, authorities took special care to supply the city, and in guaranteeing its distribution among the whole population, even in periods of dearth ${ }^{32}$.

Beginning in the mid-seventeenth century the food supply system of Madrid underwent a series of changes lasting until the 1740's. In the case of bread, the compulsory purveyances of the Pan de Registro lost their importance, although they were not officially discontinued until 1758. In their place, muleteers from Segovia and Ávila began to convey wheat and sunflowers from different parts of Old Castile for sale to bakers in Madrid and nearby villages specializing in the production of bread (Vallecas, Getafe, Vicálvaro, and Villaverde). The municipal granary remained as an

${ }^{30}$ For the decline in real salaries, see E. J. Hamilton, War and Prices in Spain, 1651-1800, Cambridge (Mass.), 1947, p. 233-271; and J. Soubeyroux, Paupérisme et rapports sociaux à Madrid au XVIII e siècle, Lille-Paris, 1978, vol. 1, p. 64-90. The concentration of urban property and the evolution of housing rents are examined in El impacto cit., p. 247-249 and 275-277. Data for 1750 in relation to the changes in fiscal pressure can be found in ibidem, p. 321; data for 1792 are calculated by dividing the 24,420,568.85 reales collected by Royal and Municipal Exchequers by the 190,000 inhabitants of Madrid in that year. For the level of municipal income, see C. de la Hoz García, Fiscalidad y Hacienda Municipal en el Madrid del siglo XVIII. Las sisas (1680-1808), M.A. diss., Universidad autónoma de Madrid, 1985, apéndice 1. For the value of income derived from the rentas provinciales del casco, see J. Zafra Oteyza, Fiscalidad y Antiguo Régimen. Las rentas provinciales del Reino de Granada (1746-1780), Madrid, 1991, p. 210.

${ }^{31}$ D. R. Ringrose, Madrid, table 4.8, p. 85.

32 J. U. Bernardos Sanz, Mercado y abastecimiento, 1561-1850, in Madrid. Atlas, p. 232-243, p. 232. 
alternative source of supply, and its resources let the authorities control provisioning during periods of shortage. Other essential products such as meat, oil, or charcoal continued to be provided by obligados, merchants or companies who had the monopoly of supplying the capital in exchange for fees paid to the Municipal Council, in the aim of guaranteeing sufficient provisions at reasonable prices. The system of obligados was supervised by the Sala de Alcaldes and the aldermen. Wine was the only product purveyed out of the obligados system; its supply rested in the hands of private persons and institutions ${ }^{33}$.

In the early eighteenth century, the supply system was affected by changing trends in agrarian production. During subsistence crises in particular, private channels of provisioning gave pride of place to public authorities, who were obliged to undertake important purchases at high costs. Poor harvests at the beginning of the century, and again during the 1730 's, forced the municipal granary to import large quantities of wheat from Andalucía and even further afield, from places such as Sicily. These purchases had to be paid by the Municipal Council, the Royal Exchequer, and private entities such as the Cinco Gremios Mayores (Five Major Guilds).

In the case of meat, financial losses and other difficulties forced the system of butcher shops under private management to return to the supervision of public authorities from 1728 to 1741. But public management only increased the financial costs provoked by the crisis years of the 1730s. Such structural realities wound up engendering huge deficits. Supplies themselves were neither abundant nor close by, as during the sixteenth century, for the exploitation of marginal lands had reduced the size of pastures, thus making imports more expensive. From the point of view of demand, high meat prices were the consequence of increasing fiscal pressure upon this product, which doomed the possibilities of a more flexible market and an effective fight against fraud ${ }^{34}$.

After a new attempt to re-establish the system of meat supply through the obligados, in 1743 the Junta de Abastos (Supply Board) was created. This organism, presided over by the Governor of the Council of Castile and including a councillor of the Royal Exchequer, the Corregidor, a representative of the municipal government and two aldermen was charged with guaranteeing the provision of meat, fish, oil, salt pork, tallow candles, charcoal, and, beginning in 1744 , bread, through an strict

${ }_{33}^{3}$ J. U. Bernardos Sanz, No sólo de pan, p. 100-153 and 305-333.

${ }^{34}$ El impacto cit., p. 355 . The deficit of meat obligados from 1677 to 1727 is specified in J.U. Bernardos Sanz, No sólo de pan, p. 358. 
monopoly. From that date onwards, the fate of the provisioning system in Madrid remained linked to the evolution of the royal finances. The increase in the latter's level of debt led eventually to the collapse of the absolutist state, and with it the market of Madrid ${ }^{35}$.

The Junta de Abastos turned to the Municipal granary as a mechanism for assuring wheat supplies. To this end, the Supply Board sent commissioners all throughout Castile in order to purchase sufficient wheat. Infrastructures were moreover refurbished through the building of new granaries in Arévalo, Navas de San Antonio y Guadarrama, the construction of mills in the hills close to Madrid, and the enlargement of the Pósito, all of which favoured the transport and storage of wheat destined for the Court ${ }^{36}$. At the same time, the Supply Board obliged bakers in Madrid and Vallecas to purchase wheat from the municipal granary even during good harvest years, which further consolidated the monopolistic position of the Pósito.

Despite the investments made in the provisioning system and the control imposed by the Junta, this organism could not prevent the rise of food prices. This was thanks to the inertia of the socio-economic structure consolidated in Castile after the seventeenth-century crisis. On the supply side, the backwardness of rural communities, together with the concentration of wealth in privileged hands impeded an effective response to the growing needs of the expanding capital. On the demand side, the impoverishment of the popular classes worked against a balanced diet, except when the authorities intervened to provide subsidised food. Any instance of the latter, however, had serious consequences for the broader system of public finance, as subsidising food meant not paying off the consolidated royal debt and municipal bonds. In such circumstances, public management worked well until the recurrence of extremely virulent production crises. In terms of meat supply, once the radius of purchases extended due to the decrease of pasturage for cattle, in the crisis of 1764-66 all the gains obtained in previous years - more than a million reales - were spent buying meat and subsidising the losses incurred during these three years. During the same crisis, the Pósito had to import from the Mediterranean coast more than 28,000 tons of wheat, which also brought dramatic losses to its managers ${ }^{37}$.

${ }^{35}$ J. U. Bernardos Sanz, Mercado, p. 237; and El impacto cit., p. 355-356.

${ }^{36}$ The construction of $16 \mathrm{Km}$. of a new road along the pass of Los Leones toward the end of that decade facilitated the transport of goods. See S. Madrazo Madrazo, El sistema de transportes en España, 1750-1850, vol. I, Madrid, 1984, p. 162.

${ }^{37}$ J. U. Bernardos Sanz, No sólo de pan, p. 461-469. 
Within the city, the Sala de Alcaldes was in charge of maintaining public order and the supply of essential products. Although the prices of food and other merchandise were regulated by the public authorities, numerous dealers hoarded foodstuffs - such as salt pork, wheat, or barley in order to sell them in periods of rising prices. The magistrates of the Sala had to work hard to eradicate fraud. They initiated many criminal prosecutions against shopkeepers who sold adulterated oil, or fish and other foodstuffs in poor shape, along with other individuals who illegally traded in foodstuffs. They also prosecuted peasants from nearby villages for contraventions of municipal price policies that tried to guarantee a regular supply of bread, wheat, barley, and other grains.

Public authorities moreover had to fight the high level of corruption among officials and other servants of municipal and royal institutions. Few measures adopted against them seemed to have any effect. Between 1700 and 1766, 445 police officials and personnel of the administration of justice were charged with fraud and other illegal activities in relation with the supervision and control of the prices and norms regulating the sale of food. Private dealers and people working in food distribution and supply were also frequently involved in criminal cases during the period under consideration. In 1709, for example, the court of the Sala dealt with a case of swindle, theft, and false currency involving 105 defendants, of whom 31 were officials of the Madrid city council or from the Sala itself ${ }^{38}$.

Smuggling was the most widespread of the illegal activities concerning the food supply. The level of complaints by tax collectors certainly encourages one to think so. In fact, so much wine was introduced into Madrid in exchange for small quantities of money paid to the gatekeepers that in 1682 the corporation in charge of wine distribution gave up the obligación contract due to the losses of money caused by such smuggling. In 1693 a new watch was created in order to prevent such activity, and new and harsh punishments were decreed for those in charge of wine distribution that failed to fulfil the obligations signed in their contracts. Ten years later, all exemptions from wine taxes were suppressed. In 1717 all patrols of watchmen were unified under the direction of the Superintendencia General de Rentas de la Real Hacienda (General Superintendence of Income of the Royal Exchequer). However, this failed to end illegal trade; thus measures attempting to suppress it continued to be proclaimed throughout the rest of the century. In 1735 restrictions on

${ }^{38}$ A.H.N. Consejos, libro 2.788, ff. 336-341. 
the distribution of wine were imposed beyond the city walls; in the same year the sale of wine within a radius of $10 \mathrm{~km}$ around the city was prohibited. In 1763 the same measure was extended up to $15 \mathrm{Km}$. Between these two dates, patrols of watchmen were continually maintained, and muleteers were obliged to present at the city gates certificates of origin, transit, and destiny of their weights, which were to be entered into the register books ${ }^{39}$.

Apart from fraud and smuggling, the authorities had to face another type of criminality whose causes were rooted less in the defects of the supply system, and more in the organisation of society as a whole, especially the highly unequal distribution of resources. Actually, a high percentage of offences registered in Madrid during the eighteenth century were of an economic character, even when they fell outside of the category of property crimes, such as those linked to prostitution or cohabitation, not to mention vagrancy or poverty, which normally pertained to the group of moral offences. To live together without benefit of marriage was a crime in Early Modern Castile, and a number of men and women prosecuted for this offence declared before the judges that the only reason they cohabited was they lacked the means to get married.

Between 1700 and 1766 the Sala de Alcaldes recorded 16,957 criminal cases involving 30,363 defendants, of whom 24,625 were men, and 5,738 women. These figures included all kind of illegal acts and behaviour, from a notorious case of murder to a simple failure to heed regulations. The number of offences and offenders in Madrid reveals rates of criminal activity and repression close to those found in other major European capital cities such as London, Paris, and Amsterdam ${ }^{40}$. The dockets of criminal cases also included the name of defendants who were prosecuted for partial evidence or suspicion of criminal behaviour (almost 1,500 and 130 respectively), as well as attempted crimes (near 350). Of the total number of offenders, 3,225 were prosecuted for crimes committed outside the city of Madrid. Moreover, almost 30 percent of those charged with felonies were eventually acquitted due to insufficient evidence ${ }^{41}$.

${ }^{39}$ On smuggling and the measures to prevent it, see C. de la Hoz García, Fiscalidad, p. 34-36. Similar measures to control the traffic of muleteers were adopted in other European capital cities during the same period, as in the hinterland of Paris, where muleteers were obliged to show lettres de voiture to legalize the circulation of their merchandise. See C. de Castro, El pan, p. 28.

${ }^{40}$ Á. Alloza Aparicio, La economía criminal, p. 197.

${ }^{41}$ For a quantitative study of crime in eighteenth-century Madrid, see Á. Alloza Aparicio, La delincuencia en Madrid durante el siglo XVIII. Una historia social, Ph.D. diss., Universidad autónoma de Madrid, 1996, p. 268-320. 
Despite the efforts of the authorities to prevent crime in Madrid, the period from the mid-seventeenth century to 1765 saw a major increase in registered offences. In the final decades of the 17th century the Sala de Alcaldes initiated annually an average of 120 cases, while during the central decades of the eighteenth century the magistrates brought to the docket more than 300 cases a year. The increase in the average number of crimes clearly exceeded contemporary population growth. Moreover, at this point groups of pickpockets and petty thieves began to appear in the city, always working in collusion with officials of the Sala de Alcaldes ${ }^{42}$.

The extent of criminality was not only linked to the growth of «common» delinquency; it also had its origins in the social exclusion of a number of poor people. While the offenders involved in criminal cases number a few hundreds each year, more than 2,000 vagrants and beggars were apprehended by the police in the streets of Madrid during the second half of the eighteenth century. This was the direct result of the criminalization of poverty and vagrancy : between 1745 and 1751 a number of edicts and laws were enacted to identify and arrest those without jobs (ociosos), who spent the day in taverns (malentretenidos), who did not want to learn a trade (inaplicados) and, of course, those who had no place to live in. These decrees exhorted the marginal people to enter into the hospices on their own, or else they would be arrested and committed to these institutions or, depending on circumstances, sent to the royal armies, African fortresses, or hard labour in public works and roads ${ }^{43}$.

The incidence of violent offences, in particular murders, aggravated assaults, and malos tratos (personal injuries) was dramatically high during this century, and totalled 30 per cent of recorded crime. However, the rate of homicides tended to decline toward the close of the period. Property crime represented one-fifth of the total registered crime, but public authorities were tempted to repress offences against property with more energy than any other crime. In 1734 a Capital Punishment Act was passed for people who committed theft or burglary within Madrid and its hinterland. This exceptional measure was debated by magistrates of the Sala de Alcaldes, suspended temporarily, and later re-established ${ }^{44}$.

${ }^{42}$ Ibid., p. 145-164.

${ }^{43}$ Figures of arrested vagrants between 1730 and 1781 can be found in M.R. Pérez Estévez, El problema de los vagos en la España del siglo XVIII, Madrid, 1976 , p. 119. In the same period the earliest form of identity card (pasaporte) was created and demanded of all migrants to Madrid. See El impacto cit., p. 469.

${ }^{44}$ Capital Punishment Act, in A.H.N., Consejos, libro 1.477, 5. A discussion of this law and its charactristics and consequences, can be found in F. Tomás y 
One of the main aims of these frightening measures was to fight incipient criminal organisations. Magistrates observed how some delinquents co-operated in organised groups in order to commit thefts, and even specialised in specific property crimes. However, harsh punishments did not deter such criminal behaviour. On the contrary, criminal records show a rise in the activity of these semi-professional thieves during the 18th century : between 1750 and 1770 two or three gangs of pickpockets and petty thieves were apprehended yearly by police ${ }^{45}$.

Punishment constituted the more frequently employed means of repression of criminality. The more than 9,000 felons who were condemned to fortresses, galleys and the royal mines at Almadén between 1668 and 1780 form, together with several thousand other persons condemned to other penalties in eighteenth-century Madrid, a good statistical sample with which to examine the types of punishments imposed. Along with fines and penalties such as banishment, more than a half of the total persons condemned were sent to the fortresses of Orán, Melilla, Ceuta, Alhucemas, and the Peñón de Vélez in La Gomera. There the plebeians among them were employed in hard labour and the privileged in military services. Other felons were sent to Mediterranean galleys and the mercury mines at Almadén, where they experienced extremely high mortality rates due to the harsh working conditions, which included the emission of gases from the amalgam process. Women were sent to the Galera (prison for females) and diverse Casas de recogida, where inmates were re-educated through work and prayer, in order to learn a more role within corporate society ${ }^{46}$. The most serious crimes met with the death penalty, although the actual application of this extreme measure was very selective. The eighteenth century witnessed an annual average of 2 executions per 100,000 inhabitants; all of them were hanged, burned, decapitated or garrotted at the Plaza Mayor or the Plaza de la Cebada. This contrasts with the 4 or more executions per 100,000 inhabitants that took place yearly in London during the same period ${ }^{47}$.

Valiente, El derecho penal de la Monarquía absoluta (siglos XVI, XVII y XVIII), Madrid, 1969, p. 45, 253, 322, and 346.

${ }^{45}$ Organized crime can easily be observed in other European capital cities. See J. L. McMullan, Criminal organization in sixteenth and seventeenth century London, in Social Problems, 29, 3, 1982, p. 311-323, and F. Egmond, Underworlds. Organized crime in the Netherlands, 1650-1800, Oxford, 1993.

${ }^{46}$ For a more detailed study of punishments in eighteenth-century Madrid, see Á. Alloza Aparicio, La delincuencia, p. 332-369.

${ }^{47}$ For Madrid, see Ibid., p. 332-369. For London, see P. Linebaugh, The London hanged. Crime and civil society in the eighteenth century, London, 1991, p. 151-163. 
The growing feeling of vulnerability to crime since the very beginning of the eighteenth century led to a series of changes and reforms in the system of control and repression. Immediately following the War of Spanish Succession, Felipe V attempted to renew the Sala de Alcaldes with a Nueva Planta decree changing the composition and structure of this mayor police institution, and at the same time dividing Madrid into 18 districts. In the end the reforms of the Bourbon king failed to produce any real changes, apart from the creation of two new posts of Magistrates in 1715 , and of a new police district 35 years later ${ }^{48}$.

At the same time, the maintenance of the public order was militarised. In 1713 Felipe V created the Cuerpo de Inválidos (Corps of disabled veterans) as a permanent force to assist the Sala de Alcaldes in its night patrols and in other tasks related to public order. At the end of the War, the majority of soldiers formerly housed in the villages around the capital city were concentrated in the city itself, while a new tax was levied in order to build barracks to host the soldiers now permanently assigned to duty in the city near the king. All these measures did not put an end to crime. Thus in 1761 Carlos III increased the existing number of barracks for Inválidos from 20 to 28, and issued a royal decree creating a milicia urbana (urban militia) composed of guildsmen. Finally, apart from the Sala and the municipal officials, from 1761 onwards public order in Madrid was maintained by 1,534 uniformed men, comprising a company of grenadiers and 9 regiments of fusiliers, which patrolled the streets together with 500 urban militiamen every two hours ${ }^{49}$.

The central decades of the eighteenth century saw intensified repression. It also witnessed special attention devoted to the external aspect of Madrid, which - from the perspective of Esquilache, Carlos III's Prime Minister - should be in consonance with the majesty of its leading resident, the king of Spain. Among the measures of this 'modernisation' program were the redesigning and decoration of certain urban squares, the elimination of dirt in public areas, the construction of drains along the main roads, and the installation of street lighting in order to prevent crime. Some of these measures provoked opposition among the popular classes, especially when they led to higher prices. The reform of old buildings obliged their owners to increase rents. The introduction of 2,000 lamps,

${ }^{48}$ El impacto cit., p. 172, and C. de la Guardia, Conflicto y reforma en el Madrid del siglo XVIII, Madrid, 1993, p. 151-163.

${ }^{49}$ By 1760 , the monarchy assigned to Madrid more companies of Inválidos than those quartered in Galicia and Old and New Castile together. See J. L. de Pablo Gafas, Justicia, p. 236-246. 
called esquilaches by the populace, led to a rise in the price of oil and a run on tallow candles, thus condemning the homes of many poor families to darkness. One decree even modified certain traditional clothing of Madrid in order to permit better identification of those suspected of crimes ${ }^{50}$.

The situation created by this 'modernisation' program was not as bad as that caused by the rise in the price of basic products, such as bread. Its price increased from 0.7 reales to 1.4 during the first months of 1766 , largely as the result of very poor harvests in 1764 and 1765 . With a popular salary of 4 reales a day, most people could purchase at best three pieces of bread. Meanwhile, the failure to apply to Madrid the Free Trade in Grains Act of 1765 in order to maintain public peace wound up aggravating scarcity and favouring speculation. Since the Marqués de Esquilache was behind all these measures, and at the same time was the head of the Junta de Abastos, he easily became the target of popular anger ${ }^{51}$.

There were, then, motives for revolt, and the riot known as the Motin de Esquilache began on March 23th 1766. On that day, about 15,000 people destroyed the new lamps, sacked the residences of Esquilache and Sabatini, freed those imprisoned for violating the clothing ordinance, assaulted the barracks of soldiers and guards, and openly challenged the royal armies. Their aims were clear : the banishment of Esquilache, his

${ }^{50}$ The urbanistic reforms of the reign of Carlos III are studied in F. J. Marín Perellón, Madrid : ¿una ciudad para un rey?, in Equipo Madrid, Carlos III, Madrid y la Ilustración, Madrid, 1988, p. 121-151. For opposition to new policing measures, in particular regarding clothing, see A.H.N., Consejos, libro 1.328, ff. 931r.-934v.; P. Vilar, El 'Motín de Esquilache' y las crisis del Antiguo Régimen, in Revista de Occidente, 107, 1972, p. 199-249; and T. Egido, Madrid 1766 'Motines de Corte' y oposición al gobierno, in Cuadernos de investigación histórica, 3, 1979, p. 125-153.

${ }^{51}$ For the fall in agrarian production and the parallel rise in the price of grains, see P. Vilar, El Motín, p. 205, and G. Anes Álvarez, Antecedentes próximos del Motín contra Esquilache, in Moneda y crédito, 128, 1974, p. 219-224. For their relation with the Free Trade in Grains Act, see P. Vilar, El Motín, p. 210-212; L. Rodríguez, Campomanes y el libre comercio de granos, in her Reforma e ilustración en la España del siglo XVIII. Pedro Rodríguez de Campomanes, Madrid, 1975, p. 179-221; J. U. Bernardos Sanz, Madrid y la libertad del comercio de granos, in Equipo Madrid, p. 103-124; and C. de Castro, Campomanes. Estado y reformismo ilustrado, Madrid, 1996, p. 139-144. The decree liberalizing the trade in grains was similar to others enacted in different absolutist states of Mediterranean Europe, such as France, where its capital and its hinterland also were excluded. See E. Le Roy Ladurie and B. Quilliet, Baroque et Lumières, in G. Duby (dir.), Histoire de la France urbaine, III, Paris, 1980 , p. 293-524, p. 338. It is possible that the riot was also inspired by Jesuits and several members of privileged classes, who opposed Enlightened reforms. See L. Rodríguez, El Motín de Madrid de 1766, in Revista de Occidente, 121, 1973, p. 24-49 and T. Egido, Madrid, p. 143-148. 
replacement by a Spanish minister and, above all, a reduction in the price of bread and other essential foodstuffs. The suppression of the Junta de Abastos, together with the derogation of the Royal decree against popular clothing were among the other demands. The crowd managed to scare Carlos III and, eventually, achieved many of its goals. The frightened king left Madrid and found shelter in Aranjuez the night of March 25th ${ }^{52}$.

A few days later, once public order was re-established in Madrid, the authorities initiated a crackdown, and hundreds of people were arrested and punished. However, the riot against Esquilache produced paradoxical results, especially when similar riots broke out in other 40 towns and cities all over the Kingdom. Indeed, although order was eventually reestablished, Carlos III had to reduce the price of basic products. While this reduction led to an additional deficit of almost one million reales, he also opted to suppress the Junta de Abastos, an institution that personified the traditional supply system of Madrid. In the end, moreover, Carlos III also sacked the Marqués de Esquilache, who at that time had been one of the main promoters of the free trade in grains ${ }^{53}$.

\section{A Court to be envied?}

At the end of the eighteenth century Madrid's authorities happily governed one of the most peaceful courts in Western Europe. In the eyes of these committed partisans of enlightened reform, there was no doubt about it : in comparison with the revolutionary movements in Paris, and the continuous riots, strikes and crime in London, Madrid was an Court to be envied ${ }^{54}$.

There were, of course, good reasons for their satisfaction, given that Madrid was well supplied and a city thoroughly under control. However,

52 The geography of the Esquilache riot and its evolution is detailed in J. Espinosa Romero, J. A. González Pañero and J. A. Nieto Sánchez, El conflicto social, in Madrid. Atlas, p. 224-231, maps 102-105.

${ }^{53}$ For the characteristics of the riots occurring in different cities during the same year, see P. Ruiz Torres, Los motines de 1766 y los inicios de la crisis del Antiguo Régimen, in B. Clavero, P. Ruiz Torres and F. J. Hernández Montalbán, Estudios sobre la revolución burguesa en España, Madrid, 1979, p. 49-111. The paradoxical results of these riots are examined in J. U. Bernardos Sanz, No sólo de pan, p. 463-470.

${ }^{54}$ F. Hernández Sánchez, La Corte envidiable. Delincuencia y represión en el Madrid de Carlos III, 1759-1788, in Equipo Madrid, p. 331-353. 
the food supply system generated very high expenses, which were paid by the popular classes of the city and its hinterland. Immediately following the suppression of the Junta de Abastos, provisioning was transferred to private hands, under the supervision of the Municipal Council. The Pósito subsisted, and stored sufficient supplies of grain to be sold directly to bakers. Despite these liberalisation measures, commercial agents did not manage to increase the overall supply, nor could they prevent the rise of prices of all products.

The origin of all these phenomena can be found in the situation of Castilian agriculture during the second half of the 18th century. The growth in urban population provoked the extension of the areas of provisioning, given that the expansion in agrarian production itself was based on extensive agriculture. Growth in arable land ended up breaking the precarious balance of the rural economy : the ploughing of meadows, grazing lands, and woodlands reduced the space for the production of charcoal, and made more expensive the grass needed to feed livestock. Beginning in the 1780's the price of wheat in Castile increased, which brought profit only to large-scale rentiers, the true beneficiaries of the free trade in grains. The rise in prices led to new difficulties in the supply of wheat to Madrid. As a result, the Pósito was forced to increase its purchases of grain. The supply of meat also lagged behind, and it had to be purchased as far away as Galicia, Portugal, France, and Morocco. Under these circumstances, the rising losses of the city Council and particular among the traders forced between 1786 and 1794 the transfer of the management of supply to the Cinco Gremios Mayores and, at the very end of the century, to a new central government office, the Real Dirección de Abastos, which essentially meant a return to the system prior to the Esquilache Riot ${ }^{55}$.

The Real Dirección de Abastos managed to maintain the wheat supply during the difficult years of 1801-1804. However, the enormous deficit it incurred made it impossible to continue the old system of supply. The result was definitive liberalization in 1805 . By that time, the debts contracted in order to defray the deficit brought on by expensive purchases were frightening : during the period 1795-1798 alone the losses of the city Council amounted to 34 million reales, a sum equal to the total income of the municipality during those three years. But the truly huge debt was that of the Pósito : between 1785 and 1805 the Bank of San Carlos, the Royal

${ }_{55}^{5}$ J. U. Bernardos Sanz, Mercado, p. 238, and No sólo de pan, p. 455-554. 
Household and the city Council lent the Municipal Granary no fewer than 135 million reales. Of course this situation aggravated the financial difficulties of the royal and city treasuries and, most of all, reduced the purchasing power of the inhabitants of Madrid and its hinterland, subjected as they were to new taxes, both direct and indirect ${ }^{56}$.

In Madrid, the loss of purchasing power by the working population, the high level of taxation of basic products, and the increasing prices of all kinds of foodstuffs impoverished the daily diet of the popular classes. As in other European capital cities in the mid-eighteenth century, half a kilo of bread constituted the main calorific support for most people. It is true that meat, fish and animal fats were still in demand by the populace, as proved by the fact that these products were still supplied by the Junta de Abastos. But this fact could not hide the reality : from the end of the sixteenth century, the per capita consumption of meat and wine fell dramatically, because if in 1591 a citizen of Madrid consumed 120 grams of meat (basically mutton) and almost half a litre of wine a day, at the end of the eighteenth century he got only 71 grams of beef, 20 grams of pork, 0.13 litres of wine, and 68 grams of chocolate, a new calorific source highly appreciated by the population.

A similar impoverishment of the popular classes diet took place in other European capitals during the same period. Bread, with an average of 457 grams a day in Rome, or of 800 grams in Naples and Paris, became the main source of calories for the masses. The increasing consumption of bread was paralleled by the decline of meat in the popular diet in these cities. However, the reduction of wine consumption observed in Madrid was linked to the rise in its price due to the 15 different indirect taxes which burdened this product. That was not the case of Rome, Palermo,

\footnotetext{
${ }^{56}$ For the financial debts incurred by the municipal managers between 1795 and 1798 , see Ibidem, p. 496. For the debt of the Pósito, which at the beginning of the $19^{\text {th }}$ century was 10 times higher than the total amount of the annual taxes collected by the Royal Exchequer in Madrid, see C. de Castro, El pan, p. 266. In order to pay these debts, the royal and municipal Exchequers had to use the rent obtained from excise taxes upon consumer goods (sisas), which were originally intended to pay the consolidated royal debt and municipal bonds. Thus the difficult position of the municipal granary contributed to the failure of both public institutions. In fact, in 1819 arrears of municipal bonds exceeded 142.6 million reales, a sum equal to 70 per cent of the consolidated municipal debts's nominal values. See C. de la Hoz García, Fiscalidad, p. 87. In the case of other Southern European capital cities, such as Rome, the financing of the supply system also contributed to the growth of consolidated state debt. See D. Strangio, Crisi alimentari e politica annonaria a Roma nel Settecento, Roma, 1999.
} 
Naples or Paris, where the level of wine consumption was two or three times higher than in Madrid ${ }^{57}$.

To compensate the deterioration in nutrition, people had to resort to fiscal fraud by means of smuggling. The case of wine is very illustrative, because people went to the villages of the hinterland of Madrid to purchase it at cheaper prices, or simply bought it in the city's black market ${ }^{58}$.

In Madrid, the arrival of thousands of mobile poor also caused problems of public order. Poor peasants reached the city attracted by the social patronage exercised by the king, which took the form of cheap bread and a poor relief system which covered the minimal necessities in extreme cases. However, employment fell dramatically during the second half of the eighteenth century, and these contingents of idle poor and vagrants were confined in hospices, following an active campaign against them led by a newly founded institution. In fact, two months after the Esquilache riot, the Comision de Vagos (Commission for the detention of vagabonds), an institution originally founded in 1631 as an adjunct to the Sala, was militarised, with the aim of increasing its efficiency in the repression of vagrancy. Between 1766 and 1768, 5,970 vagrants were arrested and confined into the Hospicio of Ave Maria and the Remand Home of San Fernando. Both centres were soon transformed into authentic jails, used as instruments for social prophylaxis ${ }^{59}$. In 1786 alone, 3,347 vagrants were

${ }^{57}$ Data for per capita consumption in Madrid are found in El impacto cit., p. 356-360, especially figure 18; J. U. Bernardos Sanz, Mercado, graph 73; and D. R. Ringrose, Madrid, table D-8. For references to other cities, see M. Livi-Bacci, Ensayo sobre la historia demográfica europea. Población y alimentación en Europa, Barcelona, 1988, p. 137-139, and M. Montanari, El hambre, p. 105-108, and 128-146. Data on daily per capita consumption of bread and wine in Rome, Palermo, Naples and Paris, in J. Revel, Les privilèges d' une capitale : l'approvisionnement de Rome à l' époque moderne, in Annales, E.S.C., 30, 1975, p. 563-573; M. Aymard and H. Bresc, Nourriturres et consommation en Sicile entre XIV et XVIII ${ }^{e}$ siècle, in Annales, E.S.C., 30, 1975, p. 592-599; B. Marin, Naples, p. 153; J. Jacquart, Paris, p. 110, and F. Braudel, Civilización material, economía y capitalismo, I, Madrid, 1984, p. 196.

${ }^{58}$ With this in mind, our figures of per capita consumption should be increased, but the limits on available documentation prevent our doing it. References to illicit trade, fraud and smuggling with wine can be found in C. de la Hoz García, Las reformas de la Hacienda madrileña en la época de Carlos III, in Equipo Madrid, p. 77101, p. 97.

${ }^{59}$ For the Comisión de Vagos see J.L. de Pablo Gafas, Justicia, p. 421-423. The number of persons arrested by this institution is reported in R. M. Pérez Estévez, El problema, p. 119 and J. Soubeyroux, Pauperismo, p. 159. For an examination of the hospicios in Madrid, see El impacto cit., p. 442-446; for their development as prisons, see P. Trinidad Fernández, Asistencia y previsión social en el siglo XVIII, in Seminario de historia de la acción social, Madrid, 1986, p. 89-115, especially p. 92-93. 
arrested, of which the half were acquitted after summary trials, while the other half were jailed or destined to hard labour in public works and other construction projects, or sent to the royal army if the physical and mental conditions of the male inmates permitted $i^{60}$.

During the second half of the eighteenth century new institutions for poor relief were created in Madrid. Until the middle of the century such relief was in the hands of a number of brotherhoods and fraternities, which were able to cope with the necessities of around 45 per cent of the artisans of the city, along with 17 hospitals founded by private persons particulars and managed by ecclesiastical organizations. From 1754 most of these hospitals were put under the aegis of the absolutist state through the Junta Real de Hospitales (Royal Hospitals Board). Moreover, in 1778, two new institutions (the Diputaciones de Barrio and the Junta General de Caridad) were founded with the purpose of assisting the poorest inhabitants of Madrid, either by employing some people or distributing food in the humblest areas of the town. In 1781 the new Hospital General de Atocha was finished and began to attend to the idle poor. The records of these hospitals and other institutions, including poorhouses, show an spectacular rise in poor relief : while by 1759 they assisted some 16,000 persons, in 1774 the figure was above 25,000, and reached more than 30,000 during the first decade of the 19 th century ${ }^{61}$.

Important reforms also affected the institutions in charge of the administration of justice, government, and police. In October 1768, the Crown reformed the Sala de Alcaldes. For criminal matters, a royal decree ordered the division of the Sala into two, made up of five magistrates in each. At the same time, 8 provincial courts for civil suits were founded exnovo. In terms of public order, infantry guards comprising 20 enlisted men and one officer were distributed along the main nodes of the urban space, while the government also assigned one company of Inválidos to each of

${ }^{60}$ F. Hernández Sánchez, La Corte, p. 348 and J. L. de Pablo Gafas, Justicia, p. 501-630.

${ }^{61}$ The pauperization of popular classes is also reflected in the records of children abandoned (expósitos) in La Inclusa, or Foundling hospital. In 1752 the number of expósitos was equal to 15.37 per cent of all births in Madrid. At the end of the century this figure had risen to $23 \%$. See El impacto cit., p. 166. For the general evolution of poor relief systems in this period, see E. Sánchez de Madariaga, Cofradías y sociabilidad en el Madrid de la edad moderna, Ph.D. diss., Universidad autónoma de Madrid, 1996, and J. L. de los Reyes Leoz, Carlos III, padre de vasallos, in Equipo Madrid, p. 355-377. The number of persons treated in hospitals between 1759 and 1807 can be found in J. Soubeyroux, Pauperismo, p. 111, 136. 
the 64 districts of Madrid. As a result of this militarization of public order, the city became a sort of barrack, subject even to a curfew ${ }^{62}$.

From that moment onwards, and especially after the promulgation in 1774 of a Royal Pragmatic authorising the suppression of riots, the Royal Army consolidated its role in the maintenance of public order. The changing number of soldiers posted to Madrid clearly illustrates this phenomenon : in 1750 there was one soldier for every 47 inhabitants; in 1804 the rate was 1 for every $16^{63}$.

The rise of recorded crime together with the expansion of vagrancy and poverty forced public authorities to enlarge the number of officials of the traditional institutions of repression, and to create new ones, such us the Alcaldes de Barrio (District Mayors) in 1768. This new figure, elected among the middle classes of the city, was created with the aim of providing information and control, rather than repression. Despite the small capacity of action of these mayors and their limited competences in criminal matters, the experience of this new institution was considered very positive, so much so that it was extended to other cities in the rest of Castile. The Alcaldes de Barrio undertook tasks such as the registration of the inhabitants of the districts under their jurisdiction, and the control of bars, shops, and coffeehouses. They also oversaw public health, hygiene, and street lighting, as well as ensuring compliance with municipal laws and decrees ${ }^{64}$.

In 1782 the Superintendencia General de Policía was created. Its personnel included members of the Sala de Alcaldes and the city Council. The principal aim of this institution was to establish a system of political control, based on espionage and other techniques of surveillance of the populace. Fear of social revolution converted the public opinion of the

62 J. L. de Pablo Gafas, Justicia, p. 219-380. The Royal decree dividing Madrid in 8 quarters and 64 districts was published in the Novísima recopilación de las Leyes de España, Madrid, 1805, Law IX, Title XXI, Book III, Chapter VI.

${ }^{63}$ F. Hernández Sánchez, La Corte, p. 342; M. Ballbé, Orden público y militarismo en la España Constitucional (1812-1983), Madrid, 1987, p. 21-37, and E. Martínez Ruiz, La seguridad pública en el Madrid de la ilustración, Madrid, 1988.

${ }^{64} \mathrm{P}$. Cuesta Pascual, Los Alcaldes de Barrio en el Madrid de Carlos III y Carlos IV, in Anales del Instituto de estudios madrileños, XIX, 1982, p. 363-390. Despite the good reputation of this institution, recent research has linked the creation of the Superintendencia General de Policía (General Superintendance of Police) to the low level of efficacy of the alcaldes de barrio; see, for example, J. L. Álvarez Caravera, El nombramiento de los alcaldes de barrio en Madrid en 1768 : el temor a la revolución social, in Anales del Instituto de estudios madrileños, XX, 1983, p. 195-202; and J. L. de Pablo Gafas, Justicia, p. 219-277. 
masses into the key to the maintenance of peace and good order. Not by accident, political satire in this period began to take on a pronounced antinoble tone ${ }^{65}$. The reports of the Superintendencia and of the secret agents of the Comisión Reservada reveal a charged political atmosphere. They came up with pasquinades, lampoons, and writings against the monarchy and the government which took the guise of crimes of opinion and illicit association. These institutions also took care to prevent any revolutionary influence from arriving from France ${ }^{66}$. Although the Superintendencia was abolished in 1792, its responsibilities were assumed by the Sala de Alcaldes.

Between 1793 and 1795 the War of the Convention worsened the existing problems of the Kingdom. Fighting the revolutionary danger in France meant increasing fiscal pressure at home. The rise of taxes provoked popular uprisings in several provinces of Castile, albeit not in the Court. In Madrid strong measures were taken against political dissent, which led to the environment of political reaction which gave rise to the Picornell Conspiracy. During the summer of 1795 the followers of Picornell tried to establish a Constitutional Monarchy through popular action. Picornell recruited a group of artisans and wage earners from the Lavapiés district, but the conspiracy was discovered due to a denunciation by some silversmiths from the Plazuela de San Miguel. The result was the banishment and imprisonment of the people who participated in the conspiracy, after having obtained a Royal Pardon of their capital sentences ${ }^{67}$. At the same time, recorded criminality increased visibly : in 1801 alone almost two thousand defendants were prosecuted for serious crimes and unlawful activity in Madrid, a level three times higher than that recorded at mid-eighteenth century. These figures reflect not only the

${ }^{65}$ T. Egido, Sátiras Políticas de la España moderna, Madrid, 1973, p. 42-54.

${ }^{66}$ One example would be the satire El Raposo (The Fox) published in August 4, 1788 in the Diario de Madrid. The clear reference in the title to the Count of Floridablanca led to the arrest of several persons. See E. Martínez Ruiz, La Seguridad, p. 119. For an analysis of this institution, see A. Risco, Espacio y control social : la Superintendencia General de Policía para Madrid y su rastro (1782-1808), in S. Madrazo Madrazo and V. Pinto Crespo (ed.), Madrid en la Época moderna: espacio, sociedad y cultura, Madrid, 1991, p. 97-127. For similar instances of police institutions created in other European states, such as Portugal, see A. M. Hespanha, De la 'Iustitia' a la Disciplina, in F. Tomás y Valiente et al., Sexo barroco y otras transgresiones premodernas, Madrid, 1990, p. 175-186, p. 185.

${ }^{67} \mathrm{An}$ analysis of this conspiracy can be found in A. Elorza, La ideología liberal en la Ilustración española, Barcelona, 1970, p. 304-309 and, by the same author, El temido Árbol de la Libertad, in J. R. Aymes (ed.), España y la Revolución francesa, Barcelona, 1989, p. 69-117, especially p. 110-112. 
growing efficacy of the expanding institutions of repression, but also the worsening social situation in Madrid at the beginning of the 19th century ${ }^{68}$.

Beginning in 1795, tithes series in Castile show a dramatic reduction in grain harvests, which initiated a phase of rising wheat prices, which by 1800-1804 had multiplied by 2.3 with respect to the levels of 1780-84. The latter subsistence crisis, linked inescapably to the model of extensive growth, had serious repercussions in Madrid, given that in the capital city bread was already the major calorific source of the popular classes ${ }^{69}$. Poor peasants crowded the streets of Madrid trying to escape the misery of rural communities, in the hope of getting some help from the poor relief system. In the spring of 1801 problems of bread supply worsened, and the public granary found it increasingly difficult to supply wheat to bakers, a phenomenon which again was related to the speculative manœuvres of intermediaries. In 1802 the preconditions for a new popular riot were already in place; and in fact, on April 6th there was a tumult in the Rastro district, in which a crowd set fire to several street stalls and bakeries. This time, the reaction of the authorities was immediate, increasing all means of control in order to keep the public peace. The turmoil was quickly and harshly repressed : the magistrates arrested and sentenced 24 people, most of them impoverished wage earners ${ }^{70}$.

Although preventive measures in the popular districts were very successful, they could not prevent hundreds of people starving to death. In 1803 the government charged the Sociedad Matritense de Amigos del País with providing poor labourers with cheap meals. At the same time public authorities tried to stop the arrival of new migrants. Some individuals, however, benefited from the crisis by withholding grains from the public granary before prices reached their height. Between March and August

${ }^{68}$ For figures on recorded crime, see A.H.N., Consejos, libro 1.393, ff. 1.067, 1.068 and 1.140 .

${ }^{69}$ This new crisis is studied in G. Anes Álvarez, Las crisis, p. 209-226; Á. García Sanz, Desarrollo y crisis del Antiguo Régimen en Castilla la Vieja. Economía y sociedad en tierras de Segovia de 1500 a 1814, Madrid, 1977, p. 87-89, 198-200 and 430-440; B. Yun Casalilla, Sobre la transición al capitalismo en Castilla. Economía y sociedad en tierra de Campos, 1500-1830, Salamanca, 1987, p. 519-520; and J. M. López García, La transición del feudalismo al capitalismo en un señorío monástico castellano. El abadengo de la Santa Espina, 1147-1835, Valladolid, 1990, p. 297-306.

${ }^{70}$ M. A. Vara Ara, Crisis de subsistencia en el Madrid de comienzos de siglo. 18001805; in L. E. Otero Carvajal and A. Bahamonde Magro (ed.), Madrid en la sociedad del siglo XIX, vol. II, Madrid, 1986, p. 245-266, especially 254-255, and J. U. Bernardos Sanz, No sólo de pan, p. 586-593. 
1804, the Pósito purchased more than 30,000 tons of wheat, 45 per cent of which came from the Baltic area and other European markets. Despite these desperate measures, 11,307 persons starved to death during that year of 1804; significantly, 69.3 per cent of them died in the hospitals of Madrid $^{71}$.

In these circumstances, given that the old centralised system of supply could not cope with necessities of both suppliers and consumers, and that the Royal Exchequer could not continue to finance its deficits, in 1805 there was no other solution but the liberalization of the main products included in the supply schedule ${ }^{72}$. After the failure of the interventionist system in operation for more than two centuries, the absolutist state ended up with only one way of preventing and suppressing public disorders : the consolidation and increase of police control over the city, by providing the Sala de Alcaldes and the Royal Army with more coercive powers. Despite these repressive efforts, however, by losing its social patronage over the Court City, the Spanish absolutist monarchy was eroding the basis of its own legitimacy.

\author{
Ángel Alloza Aparicio \\ José Miguel López García \\ José Luis de Pablo Gafas
}

\footnotetext{
${ }^{71}$ Mortality figures were four times higher than the annual average of urban decease during the $18^{\text {th }}$ century, according to M. F. Carbajo Isla, La población, p. 99.

${ }^{72}$ The causes and chronology of the crisis of the centralized system of supply in Madrid show clear parallels with the Roman case, as presented in R. Ago, Popolo e papi. La crisi del sistema annonario, in Subalterni in tempo di modernizzazione. Nove studi sulla società romana nell'Ottocento, Milan, 1985, p. 17-47, and D. Strangio, Crisi alimentari, p. 210-211.
} 